\title{
Conceptual and Methodological Issues of Poverty and Vulnerability: An Ethnographic Study from the South
}

\author{
Eswarappa Kasi \\ National Institute of Rural Development, Hyderabad, India \\ Email: kasieswar@gmail.com
}

Received December 20 ${ }^{\text {th }}, 2012$; revised January $22^{\text {nd }}, 2013$; accepted January $30^{\text {th }}, 2013$

\begin{abstract}
There is a great need to understand, analyse and critically apprise conceptual and methodological issues of poverty and vulnerability and its underlying relevance in the today's fast changing rural/urban spaces of south India. To pursue this academic and epistemological endeavour, we tried to use the existing literature largely and later tried to relate it to our own regional case for argument and discussion. This has given us a scope to look at the issues and parameters involved to see how poverty and its contiguous factors reflect upon the real people's lives and livelihoods of marginal groups in south India. Poverty should be seen in the form of loss of livelihoods, lack of access to resources, basic needs and non-availability of resources and services to the vulnerable sections of the society. Taking the case of Sugalis, one of the semi-nomadic tribe, of Rayalaseema region of south India it is argued in this paper that poverty and vulnerability coexist and strengthen each other and poverty can be understood by analyzing the real life situations and strategies adopted by the people to manage their lives. Present Paper based on an empirical research by using anthropological tools of research.
\end{abstract}

Keywords: Poverty; Vulnerability; Resources; Ethnography; Sugali; South India

\section{Introduction}

Poverty should not be viewed merely in terms of poverty line, calorie intake, etc. There is a need to understand poverty from the point of view of vulnerability. Vulnerability can be seen both as a cause and effect of poverty experienced by certain deprive section of the society. The causes and consequences of vulnerability can be observed from the ways and means of living of the vulnerable sections in the society.

Present Paper based on an empirical research conducted while carrying out my fieldwork among the Sugalis of Anantapur District of Andhra Pradesh during 2003-2004 and 20072008 as part of my $\mathrm{PhD}$ field work. The present paper tries to proceed answering four questions; what is poverty, who is the poor, why are they poor and how to resolve it? Based on these questions the present paper has been organized into three sections, where the first part deals with an extensive conceptual and methodological conversation on the existing literature on poverty and vulnerability. The second part vividly provides an ethnographic account of Sugalis and the prevailing situation in the location. The third part tried to discuss and contest the conceptual and methodological issues of poverty and vulnerability in relation to the Sugali lives and livelihoods. The fourth part of the paper provides a detailed sketch of interventions of an agency in the locality and their strategies to address the issue of poverty and vulnerability. Final part of the paper delineates the conclusions and observations.

\section{Conceptual and Methodological Conversation}

Research and writing on poverty, development and vulnerability is largely done by the academicians, researchers and agencies, both governments and voluntary agencies, across the countries of south Asia or other countries of the world. These writings further paved the way to analyze the themes and discourses on poverty and vulnerability which tries to bring mundane aspects of the terms poverty and vulnerability. Keeping these things into consideration, the present paper tries to address the issues concerned while going through the relevant literature on the themes of poverty and vulnerability; it is further linked to the empirical notions of the Sugalis and their everyday practices to overcome the notions of poverty and vulnerability (Kasi, 2009: p. 117). In South India, all the state governments have initiated measures to control poverty and address the issues of vulnerability among the dalits, dait-bahijans $^{1}$ (Ilaiah, 2009: p. 5), oppressed women, scheduled castes and scheduled tribes and other backward classes in a significant way. These efforts of the governments have brought significant changes to reduce poverty and cope with vulnerability.

Governments, both at the centre and State, have made concerted efforts to alleviate poverty through increased economic growth by using targeted programmes, land and tenancy reforms, participatory and empowerment-based approaches and the provision of basic services (Mehta \& Shah, 2003: p. 504). But development remains unattainable for 350 million of its poorest citizens. Gandhi's vision of development has been undermined through large-scale industrialization, urbanization and modernization (Saxena, 2000a: p. 6). Since 1951, Five Year plans have been adopted to propel India's development in industry and agriculture, and to remedy the political dissension, debt, and infrastructural disarray that plagued the newly inde-

${ }^{1}$ The nomenclature of Dalit-Bahujan concept has come into vogue in academia after Kanshi Ram started Bahujan Samaj Party (BSP) and he want to include all the oppressed and under-privileged castes from the backward classes into his party. For wider discussion and debate on the concept Dalit-Bahujan see Kancha Ilaiah (2009), Gopal Guru \& Geetha (2000). 
pendent country (Indian Social Institute, 1988). Development actions have succeeded in exponentially increasing India's industrial, military and agricultural production, its national income and middle class. Yet, in 2001, almost fifty-four years after independence, development has failed to alleviate poverty and related socioeconomic oppressions within the most disenfranchised caste, class and tribal (adivasi) communities (Chatterji, 2001: p. 2).

Several social anthropologists working in the field of post colonial research, globalization, development and movements tried to argue that globalization minimised the government role in developmental interventions of the poor and marginal communities (Chatterji, 2004; Kasi, 2008). For instance, Escobar (1995) viewed that development institutions continue to assert processes that systematically delegitimize traditional livelihoods by impoverishing the natural resource base upon which the lives of subsistence communities depend. In response to such neglected communities across India are operationalizing frameworks of developmental strategies that link social, cultural and economic well being of the communities. While anthropologists have made an art of integrating themselves into a local community, increasingly community has been defined less by physical contiguity or geography and more by epistemological affinity, shared meanings and common interpretative tendencies (Schwegler \& Powell, 2008: pp. 2-3). Further, it should be in accordance with the needs and aspirations of the tribal communities which would enhance their livelihood systems and strengthen their coping mechanisms in relation to vulnerability context.

Vulnerability refers to a person's state of being liable to succumb, as to persuation or temptation. Vulnerability is a concept that links the relationship that people have with their environment to social forces and institutions and the cultural values that sustain and contest them (Kasi, 2007). Moser defines vulnerability as "insecurity and sensitivity in the wellbeing of individuals, households, and communities in the face of a changing environment, and implicit in this, their responsiveness and resilience to risks that they face during such negative changes” (Moser, 1998: pp. 2-3). Bankoff et al. (2004) observed that "the concept of vulnerability expresses the multidimensionality of disasters by focusing attention on the totality of relationship in a given social situation which constitutes a condition that, in combination with environmental forces, produces a disaster".

Few writings suggest that poverty and vulnerability must be addressed with much more vigor and needs greater analysis and elaboration. For instance Pritchett et al. (2000) find that most poverty measures consider shortfalls in current income or consumption expenditures to determine the poverty line. They argue that these measures do not indicate the vulnerable among the population and therefore propose a "vulnerability to poverty line (VPL)" that is the level below which a household is vulnerable to poverty. A household with a risk of experiencing at least one episode of poverty in the near future or has a greater than 50 percent chance of falling into poverty is considered vulnerable.

Some examples of vulnerable populations are small-scale farmers, fishermen, pastoral nomads, forest populations, slum dwellers, women-headed households, traditionally marginalized groups, landless, and refugees (Mani, 2001: p. 7). Vulnerability analysis tried to address the risk and risk coping mechanisms of the poor and under privileged.

\section{Vulnerability and Risk}

Key to the discussions of vulnerability and risk in the CPRC literature is the suggestion by Hulme et al. (2001: p. 9) that:

"What poor people are concerned about is not so much that their levels of income, consumption or capabilities are low, but that they are likely to experience highly stressful declines in these levels, to the point of premature death. This approach suggests that poverty can be seen as the probability (actual or perceived) that a household will suddenly (but perhaps also gradually) reach a position with which it is unable to cope, leading to catastrophe".

This definition of poverty can also be seen as a particularly accurate proxy for a definition of vulnerability, especially due to its emphasis on the risk (whether real or imagined) of being unable to cope. However, in the CPRC literature risk and vulnerability are viewed in different ways. For example, in a discussion of the "Risk of Market Failure" Bird et al. (2002: p. 18) highlight that vulnerability to risk may be greater in remote rural areas. This "vulnerability to risk" is similar to the conception of "vulnerability to shocks" and views vulnerability as a cause of poverty. In the same way risk appears to be placed as a precursor to vulnerability. This almost comes across in a linear fashion with risk being the initial step in an assumed chain of events: "there are numerous sources of risk... which make households more likely to suffer shocks and experience an erosion of assets, deepening their vulnerability to future shocks and damaging their ability to escape poverty”.

Discussions of risk and vulnerability can also be found in the overview papers on Sri Lanka and India. Tudawe (2002: p. 28) in his observation in Sri Lanka argues that a lack of financial capital limits the ability of poor people to "manage risk and vulnerability". This idea of managing vulnerability is important, and indicates the agency of people in limiting uncertainty through having enough capacity to deal with any exposure to risk and vulnerability. Mehta and Shah (2001) highlight the relationship between risk and vulnerability through the work of Kozel and Parker (2001). They categorize the "poor" into three groups; the destitute poor, the structural poor, and the "mobile" poor. Interestingly, Kozel and Parker (ibid) assert that, while risk and vulnerability were important for all three categories, it is particularly important for the destitute and structural poor.

Further, Baulch and Hoddinot (2000: p. 19) highlight the states role in modifying the "economic, legal and political settings within which the household is embedded" and provide the examples of how macro-economic instability and the rule and law can be important sources of risk. Wisner (1993: p. 130) illustrates how the state can also be seen as a risk itself through denying the existence of hazard, directing violence towards sub-groups within the population, or orientating intervention efforts towards or away from particular locations or populations.

An attempt is made in the next section to describe about an ethnographic and empirical account of Sugalis and their location vis-à-vis in relation to their livelihoods and resources in the region.

\section{Ethnographic Account of Sugalis}

The present paper tries to describe Sugali tribe (also called Lambadi in the area), of Andhra Pradesh, which is principal tribe numerically, educationally, economically, politically and otherwise. They are concentrated in Chittoor, Cuddapah and 
Anantapur districts of the State. According to Reddy (1991: p. 613) Sugalis are not the autochthones of South India. Their original home is believed to be Marwar in Rajasthan. They came into Deccan as transporters of supplies or merchandise for the armies of Delhi emperors in their raids in the south early in the $17^{\text {th }}$ century. Some of the Sugalis returned to the north but some stayed behind and carried on petty trade with their packbullocks. They became a useful medium of transaction between the South and the North during periods of peace until 1850's. In the $18^{\text {th }}$ Century they had also taken up service under the Maratha rulers of Satara, Peshwas of Poona, the Nizam of Hyderabad and the British in their Mysore and Maratha wars (Bhukya, 2010).

With the advent of the British rule, the Sugalis gave up much of their traditional occupation of transporting goods due to introduction of mechanized transport, laying of roads and rail lines by the then government. Being poor, illiterate and lacking technical skills, they degenerated and took to crimes like robbery, dacoity, cattle-lifting and kidnapping of children until the middle of the last century. To reform them through persuasion and education was considered impossible by the British administration. There fore, in order to control their criminal activities, they were brought under the purview of the Criminal Tribes Act XXVII of 1871 (cited in Rao, 2004). According to Rao (2004) after India became independent, the Criminal Tribes Act was repealed in 1952 and the Sugalis were denotified. Till 1977, they were treated as nomadic tribe in all parts of Andhra Pradesh except Telangana region. However, the list of Scheduled Tribes has been revised by the Scheduled Castes and Scheduled Tribes Orders (Amendment Act) 1976 in order to remove area restriction in respect of the Sugalis.

\section{Location of Sugali Tribe}

The village/settlement under study is Adadakulapalle Thanda. Adadakulapalle Thanda is situated in the Adadakulapalle village Panchayat of Penukonda Mandal in Anantapur district, about 10 kilometers from Penukonda, the Mandal headquarters, of Andhra Pradesh, South India. Sugali is the numerically predominant tribe in Adadakulapalle. Among 218 households, 110 households belong to Sugali tribe with a population of 929 comprising 497 males and 432 females (Table 1). Sugali is a semi-nomadic tribe. They are still largely employed in trading service. Over a period of time their occupations, in the settlement, have changed due to changes that have come about in local conditions and technology. Traditionally Sugali are petty traders, supari (betel nut) traders, and were army personnel during Mughal period, and during the British rule they were notified as criminal tribes and after independence they were denotified. Now they are practicing settled agriculture in both the settlements (Bhukya, 2010; Kasi, 2007; Reddy, 1991).

\section{Livelihoods of the People}

The major livelihoods activities (Table 2) of Sugalis are Cultivation, followed by dairying, petty business (running owned and rented autos and kirana shop and hotel). Sugalis do go to agricultural labour, construction or repair works.

The primary livelihood activity of Sugali is cultivation, followed by daily wage labour, and petty businesses such as running one's own or rented auto-rickshaw, kirana (provisions) shop or angadi (tea and snacks stall). The majority of Sugali
Table 1.

Population distribution by sex in the settlements.

\begin{tabular}{cccc}
\hline \multirow{2}{*}{ Caste } & \multicolumn{2}{c}{ Sex } & \multirow{2}{*}{ Total } \\
\cline { 2 - 3 } & Male & Female & \\
\hline Sugali (Tribe) & $497(53.5)$ & $432(46.5)$ & $929(64.5)$ \\
Madiga (S.C.) & $96(51.6)$ & $90(48.4)$ & $186(12.9)$ \\
Kuruba & $44(50.6)$ & $43(49.4)$ & $87(6.04)$ \\
Kummari & $4(50)$ & $4(50)$ & $8(0.55)$ \\
Chakali & $39(52)$ & $36(48)$ & $75(5.21)$ \\
Valmiki Boya & $17(50)$ & $17(50)$ & $34(2.40)$ \\
Reddy & $50(56.8)$ & $38(43.2)$ & $88(6.11)$ \\
Muslim & $13(52)$ & $12(48)$ & $25(1.73)$ \\
Vaisya & $4(57)$ & $3(43)$ & $7(0.48)$ \\
Total & $764(53.1)$ & $675(46.9)$ & 1439 \\
\hline
\end{tabular}

Note: Parentheses indicate percentages. Source: Field data from the villages/ settlements.

Table 2.

Livelihoods of Sugali households in the two settlements.

\begin{tabular}{clcc}
\hline Sl. No Type of Livelihoods & $\begin{array}{c}\text { Total HHs in } \\
\text { ADP }^{*}\end{array}$ & ADP Thanda \\
\hline 1 & Wage Labourers/Land Less People & 237 & 124 \\
2 & Agriculture & 225 & 80 \\
3 & Govt. Employees & 35 & 8 \\
4 & Petty Business/Liquor Shops & $25(9)$ & $14(9)$ \\
5 & Migration & 35 & 35 \\
6 & Others/Dependents & 25 & 10 \\
\hline
\end{tabular}

Note: ${ }^{*}$ ADP means Adadakulapalle.

depends on agricultural labour and construction or repair works in and outside the settlement. Cattle, goat, and sheep are the major livestock in the area. Several varieties of grass along with stocked paddy straw; maize stalk, groundnut and bhoosa (powdered rice husk mixed with dried groundnut kernel and molasses) are used as fodder. Individual households raise country chicken in their houses.

The type of land available in the settlement is dry land and only one Sugali farmer has a bore well in his land as against 90 borewells owned by persons of other communities in the settlement. The rest of the Sugali depend upon the monsoon. Frequent failure of the monsoons has caused out-migration of people to Bangalore and Mumbai to work as construction labour or petty traders. People from the Settlement explained that seasonal migration is high among them as the majority of them are marginal farmers and landless agricultural labourers. It is worth mention here that seasonal migration does supplement investable surplus when cash needs are high and sources of institutional borrowings are few (Sah \& Sisodia, 2004, pp. 32-33). Almost half of the households in the Settlement migrate to towns in the off-season, according to the Gram Panchayat Sarpanch. One informant stated that they are helpless and there is no solution except to migrate to other areas. Younger people migrate to towns in the off seasons and come back to the Settlement during the rains, to cultivate the land or work as farm labourers. In the cities and towns the Sugali face social dis- 
crimination as migrants and also face political disenfranchisement as non-locals.

\section{Available Resources in the Locality}

Following are the common property resources available in the Adadakulapalle.

1) Village Tank

2) Forest (Unreserved/Revenue)

3) Temple land

1) Village Tank: Village tank covering the villages of Adadakulapalle and Adadakulapalle Thanda, both come under the same Panchayat. Majority of the lands situated under village tank belong to Adadakulapalle Village farmers. People felt that the tank was important as it helped in cultivation of crops like Pkm Chinta (Tamarind), sunflower and often groundnut crops. They also said that due to the tank, they are not facing the problem of shortage of power; the tank also helped increasing ground water level in the bore-wells and water levels of open wells.

People who did not have lands (irrigated) under the tank, also said that it also helped in washing clothes (women), watering to cattle etc. Grass (Jammu-local name), which is present in the water is used for making mats, covering of roof (houses or huts), and construction of sheds to small ruminants. It is also used for fencing of houses. Another important benefit from the tank is of fishing. Fishing activity is for domestic purposes where people of the village fishing activity individually and also as a group. People, who take part in the fishing as a group, share the outcome equally, and give an extra share who brings the nets.

People also revealed that, they use the tank for cultivation of cucumber crop in the tank and cattle grazing whenever the tank dried up. Majority of the beneficiaries were land less laborers, marginal and small farmers. Because of the tank landless people are getting more number of wage days as said by the informants. So villagers felt that the tank has given them both direct and indirect benefits.

2) Unreserved/Revenue forest: People of the village/ Thanda benefited by the forest as it promotes them fuel wood collection, cattle grazing, collection of Bandaru Aku (which are used for roof/leaves purposes and house fencing) and bodha grass (roof and sale purposes). But some people felt that, since they do not have cattle, it is not that important for them. Finally people believed that forest benefited them but, landless people are not much benefited due to lack of resources.

3) Temple land: According to people there are 20 acres of temple land available in the village. Earlier land was given to any farmer for a one-year duration based on auction. According to informants auction was based on a meeting, which was attended by village elders and where modalities, terms and conditions, money/amount, etc decided. The amount they got from the farmers was used for development activities of the temple and celebration of temple festivals, rituals in that particular year.

After the watershed programme was initiated into the village, the situation changed completely. Villagers conducted Gramsabha and decided to go for raising commercial crop (Pkm Chinta) in temple land. Now it is called as "chinta Topu" (Tamarind $T o p u^{2}$ ). Even though they are still using the temple land and development activities, it is used differently, so that percentage of income is more than before. They also felt that

${ }^{2}$ It is local name used by the informants to refer full of trees in a same location. there are other benefits from tamarind Topu/Trees like chiguru ${ }^{3}$ (used for curry and also they mixed it with Dal) etc. Generally women collect the chiguru and dry it for few days and use it during non-availability of vegetables or scarcity of vegetable seasons. It is also beneficial as it provides people with fuel wood. Social anthropologists works on poverty and vulnerability indicated mostly issues related to the poor and the marginalized. In the following section an attempt is made to discuss the reflection of social anthropologists from the etic perspective.

\section{Poverty and Vulnerability from the Etic Perspective}

People who live in extreme poverty, in which the very basics of life-food, security, sanitation, healthcare, education, housing and employment - are denied, are automatically denied also the right to live without fear and want. In extreme situations, these conditions might even threaten their right to life itself.

Poverty is not mere income alone. It is the social, cultural, political, and even seasonal factors that affect well-being from time to time. Women and girls are often particularly vulnerable groups in poor and marginal communities. It is evident in our case that women and children become more vulnerable due to the absence of men due to their out-migration. Men migrate to towns and cities in search of livelihoods and stay away from their family for longer duration which brings social and structural changes in the family life of Sugali tribe. Here, it is observed that women has to cope-up with partner absence and has to manage the family independently since there is lack of social safety nets such as kinship relations and social bonds.

The poor are found in every village, block and district of rural India and in every town and city. They are most numerous in areas where the land is less productive, where water is scarce, where communications are poor or where certain castes or tribes predominate. The poor are increasingly found in towns and cities as people migrate from less productive rural areas, to urban areas, where they aspire for better life. It is in this context that the relevance of anthropology and its emic engagement matters in the developmental discourse and policy formulations. Further, in its Human Development Report (HDR, 2000), it categorically stated that

"To be poor is still to be powerless and vulnerable. Life remains a torment for children in the teeming barrio of a developing country's city, for refugees caught up in conflict, for women in a society that still denies them equality and freedomevery day bringing physical and psychological threats. And still too many of the 1.2 billion people living on less than a dollar a day lack even the most basic human security".

The primary objective of the Indian Constitution is social justice. It tries to uphold the dignity of the individual, guaranteeing citizens a fundamental right to equality before the law. It promises that they will not be discriminated against, on the grounds of religion, race, caste, sex, or place of birth. It guarantees equality of opportunity in public employment, and assures personal freedoms such as the right to speech, life, liberty and religion.

The Directive Principles take this commitment a step further by instructing the state to secure a wide range of measures, including free legal aid and the citizen's right to work, educa-

${ }^{3}$ Tender leaves of tamarind. 
tion and public assistance. They also enjoin the state to ensure a living wage for all workers. Though non-enforceable, the Directive Principles declare: The state shall... strive to minimize the inequalities in income, and endeavour to eliminate inequalities in status, facilities and opportunities (Unnikrishnan, 2001).

In spite of this, the World Development Report says that over 40 per cent of the population in India lives below the poverty line, and nearly half are still illiterate. The overall figures for every aspect of development, when broken down, indicate that the poor and those who face discrimination are the worst sufferers and lack access to the basics. As the World Development Report puts it, "Poor women face a double disadvantage in access to resources and voice-they are poor, and they are women” (World Bank, 2000).

The Human Development Report 2000 found "extreme deprivation” especially among rural women from scheduled tribes. In its study of human poverty, the report says that 19 percent of India's population still lacks access to safe drinking water, a quarter does not have access to health services and as much as 71 per cent lives without access to sanitation. More than half53 percent - of all Indian children below the age of five are underweight. There are only 0.4 telephones to every thousand Indians. The top 10 percent of India's people account for 33.5 per cent of income or consumption. The 10 per cent at the other end of the scale account for a mere 3.5 per cent. Although progress has been made in areas such as literacy and life expectancy, a very large number of people remain excluded from the development that others in the country enjoy.

The World Development Report 2000-2001 noted that "Evidence from India shows that scheduled castes and scheduled tribes are among the structural poor who not only lack economic resources but whose poverty is strongly linked to social identity, as determined by caste. They also have worse social indicators."

The World Development Report (2000) estimated that 44 per cent of the Indian population still lives on less than $\$ 1$ a day. Eighty six per cent live on less than $\$ 2$ a day. Poverty figures are said to be declining but, there are more poor people in India today than the population of the country in 1947. Yet, the government celebrates the swift decline of poverty. Figures cannot communicate what "living in poverty" means or how it affects human dignity (Sainath, 1996).

The Voices of the Poor study carried by the World Development Report 2000-2001, says: "In India, the characteristics of credit institutions can deter poor people from seeking loans. Poor people in many regions also report widespread corruption in healthcare systems. But when facing serious health conditions, they feel, they have no choice but to comply with demands for bribes" (World Bank, 2000-2001).

Mehta and Shah (2003: p. 495) has rightly viewed that poverty seems to be disproportionately high among historically marginalized groups such as Scheduled Castes and Scheduled Tribes. Particularly women from these groups are more vulnerable than their male counterpart. The multiple deprivations suffered by these groups make it harder for them to escape from poverty. Caste and tribe are structural factors that predispose certain groups to long-term poverty and deprivation. The scheduled castes are a collection of castes and some of them are small and marginal farmers, most of them in rural areas work largely as agricultural labourers. The scheduled tribes were identified on the basis of certain well defined criteria including distinctive culture and pre-agricultural modes of production. Sankaran (2000: p. 509) has rightly stated that the two thirds of India's bonded laborers are from scheduled castes and scheduled tribes.

Further, Mehta and Shah (2003: p. 496) mentioned that quailtative research validate the greater vulnerability of scheduled castes and scheduled tribes to poverty. Kozel and Parker (2001) identified a typical poor household as one which is at the low end of the caste hierarchy—most often a member of the scheduled tribe... Lanjouw and Stern (1991) also postulate a strong correlation between caste and poverty in India. Based on a study, they report that among this group, poverty remains endemic. This is a reflection not only of poor endowments of productive assets, but also of low educational standards, vulnerability and little access to any kind of regular employment.

According to Hulme et al. (2001: p. 7) Poverty has many dimensions and the poor suffer deprivation in multiple ways and not just in terms of income. Several forms of human deprivation, including poor survival chances, unjust employment of children, bonded labor; environmental pollution and social exclusion are not related to income in a predictable manner (UNDP, 1997; cited in Mehta \& Shah, 2003). The poor also lack access to assets such as credit, literacy, water, and forests.

Broch-Due (1995) emphasises that the concepts of poverty employed in most development analysis are very "thin", focusing on material and measurable elements, such as income and nutrition. In contrast "thick" ethnographic work reveals far more complex, multi-layered pictures. The various concepts and definitions of poverty and wealth, or more broadly, ill being and well being, which policy agencies have emerged in specific cultural and historical contexts. Material deprivationlack of food and income, poor health-may be important everywhere. But ideas employed by African peoples in particular contexts and selected aspects of material life and also group them with other attributes in distinctive ways, form the natural focus of anthropological work in or around the topic of poverty (cited in Booth et al., 1999).

In discussions about the multi-dimensionality of poverty, it is commonplace that the ways people experience material conditions are mediated through social relations and institutions. Yet anthropological studies emphasise that well being is frequently also conceived or defined in terms of social relations and kin networks, and a person's place in them.

Anthropological work focuses attention on how experiences of poverty and well being vary over the course of people's lifetimes. The developmental cycle of domestic groups (Goody, 1971) was a key concept which drew attention to how opportunities and vulnerabilities might shift through the processes of establishing marriage, having children, children growing up, and ageing. There are links here with economists' ideas about the importance of household size, dependency ratios and so on. However, anthropologists pay attention not only to changes in economic status within developmental cycles, but also to how members at different ages and life stages may be differentially linked into wider kin networks and social relations, and hence be more or less secured and "supported".

In the following section, $\mathrm{n}$ attempt is made to look at the efforts made by the local agency to address the issue of poverty and also helping the needy in order to improve their livelihoods and which would make them to cope up with any unforeseen incidents. 


\section{NGO Intervention in the Locality}

Social Education Development Society (SEDS), an NGO, has been working in the area for the last twenty five years. It was started in the year 1980; head office is located in Mekalapalle village, which is 15 kilometers from the Mandal headquarters. SEDS facilitates government sponsored programmes and they have their own programmes in the villages. Initially, they were working in the two Mandals and now their coverage has risen to five Mandals (Penukonda, Somandepalle, Gorantla, Roddam, and Chilamathur) covering 209 villages. According to the Manager of SEDS, their main concentration is Scheduled Tribes, Scheduled Castes and other weaker sections in all their villages. In each village they have a community level organizer who is based in the village and looking after their works. Likewise, Adadakulapalle is one of their main concentrated villages in the area. Currently, the major activities of the NGO are Land Development Programmes, School Development programmes where, they construct toilets and plant trees in the school surroundings, Horticulture programmes, Women Empowerment through the formation of Self Help groups (SHGs), Water harvesting schemes and to provide minimum wage works to assist the marginal people and landless agricultural labourers (Table 3). They have initiated the unit where, all SHGs in the village to start organisation called "Village Organisation". Village Organisation has started with two people from each SHG in the village. At preset, the total strength of Village Organisation is 32 in the village. Village Organisation acts as a nodal agency in the village and undertakes all the developmental works (SEDS, 2004; Kasi, 2009).

SEDS is working for the upliftment of Scheduled Tribe and
Scheduled Caste in the village. It is observed from the table that their concentration is more on wasteland plantation, Horticulture, water conservation and land development programmes of Sugalis and SCs in the village.

\section{Land Development Programme}

Under this programme, waste lands have been converted into agricultural fields through soil conservation. Soil conservation works include Stone Bunding, Gully checks, Spill ways, Woodlots, fire tracing, ploughing, and trenching activities (Table 3). All these works are being undertaken in the summer season which provides some wage works to the people of the village. Some of the works like stone bunding, ploughing, fire tracing, and trenching, are carried by collecting some contribution from the beneficiaries. Likewise, ploughing, fire tracing and trenching activities where both have to share the work as well as money. The land development programme has benefited the Sugali in the Thanda to a certain extent only. The implementation of the programme was initiated in the year 2001 and some benefits were derived in the following year. Subsequently, due to failure of monsoons, the programme did not take off. Moreover, as mentioned before, since majority of the Sugali are landless, this programme has not been of much relevance to them. Here is a case, where the beneficiary is under the Land Development programme.

\section{Case Study of the Beneficiary from Adadakulapalle Settlement}

Ranga Naik, 55 years old, studied $5^{\text {th }}$ class, has two sons,

Table 3.

Works undertaken by SEDS during 1996-2007*.

\begin{tabular}{llccc}
\hline S. No & Activities Undertaken in Adadakulapalle Settlement & Parimanamu & Expenditure & Total Working Days \\
\hline 1 & Matti Gatlu (Mud Tanks) & 71,929 meters & 719,290 & 17,983 \\
2 & Rathi Gatlu (Rock Dams) & 17,216 meters & 172,160 & 4307 \\
3 & Rathi Maravalu & 811 (No) & 145,980 & 3649 \\
4 & Gulli Checks & 371 & 296,800 & 7420 \\
5 & Water Storage Ponds & 45 & 45,000 & 1125 \\
6 & Kuntalu & 5 & 200,000 & 2500 \\
7 & Check dams & 11 & $1,122,550$ & 18,064 \\
8 & Tree Plantation & 390,701 & 62,020 \\
9 & Seeds Implantation & 2500 Kgs & 1320 \\
10 & Horticulture & 80 Acres & $24,808,000$ & 9690 \\
11 & Roads & 20 Kms & 52,800 & 2500 \\
12 & Social Protection of Forests & 4000 Acres & 387,600 & 16,250 \\
13 & Wells Repairing & 3 (No) & 100,000 & 6000 \\
14 & Pudika Thisinadi (Check Dams and Kuntalu) & 16 & 650,000 & 4125 \\
15 & Round Sheds and Committee Hall & 4 & 24,000 & 1500 \\
16 & Bores & 7 & 165,000 & - \\
17 & Supply Channels & 8 Kms & 61,000 & 5800 \\
18 & Fish Rearing & - & 140,000 & 232,000 \\
\end{tabular}

Note: *Source: SEDS Office, Mekalapalle. 
who are separated after their marriage, has 16 acres of land in the village. The type of land is dry land and do not have water facility before. SEDS have chosen him as beneficiary and started the land development programme in the year 2000. Further, Soil conservation works were initiated with the help and support from the NGO. NGO also assisted him to go for digging bore well in his land. Later, SEDS suggested him to adopt horticulture cropping by providing saplings of Mango, Chinta (Tamarind), Eucalyptus, etc. He also reported that there are 340 mango plants in 8 acres of land, 240 tamarind plants in 6 acres of land and eucalyptus in 2 acres of land. Watering to these plants is provided through water tanker of NGO. Ranga Naik has complained that there is severe problem of forest wild pigs and cows in the area. To protect the seedlings from the forest pigs and cows, the NGO has appointed watcher, beneficiary only, by paying Rs 600/per month as a salary. Due to this problem he has to stay and sleep there in the polam (Agricultural Field) leaving his wife at home, who stayed alone in the house. His polam (land) is far off from the village, which is nearly 3 kms and electricity is not there for the land. They have complained number of times to the officials but so far they have not done anything. Officials have conveyed to them that providing electric facility to the fields is difficult since the lands are far away from the village and power lines are not available in the nearby area.

Ranga Naik said that children live in independent, separate houses post-marriage leaving parents alone. This is because of the demands and dreams of the young couples as felt by the informant. Further, he mentioned that, the traditional way of marriage is no longer practiced. Majority of the families of Sugalis are following modern type of marriages, which just last for two days and that too in marriage halls. This change is due to the improvement of communication facilities like News Papers, Television, Radio and also due to the education of the people.

In order to ensure the services of the local agency and its impact on the needy, it is also necessary to see the existing resource base and utilities, usages by the people. This will give us a scope to address the issues of resource scarcity in the study area. Hence, the next section tries to look at the available resources in the villages of study area.

\section{Conclusion/Observations}

As we said earlier, there is a need to understand poverty from the point of view of people's experiences with vulnerability and its risk factors. Vulnerability can be seen both as a cause and effect of poverty experienced by certain deprived section of the society. The causes and consequences of vulnerability can be observed from the ways and means of living of the vulnerable sections in the society. Poverty in the area is closely associated with land, available resources base and asset base and rainfall, but as agriculture is only a part of livelihood, the dynamics of poverty consists of a complex mix of processes, including migration (Kasi, 2010).

The development programmes and schemes, of NGO and available natural resource base, encompassing various issues, integrative and is idealistic efforts to address the issue of poverty by creating opportunities and offering support to individuals and individual households. At the bottom level, the programmes are burdened with problems relating to coordination of various elements that necessarily intervene and intersect the areas of operation. These include human elements-discharging the duties of the functionaries, location of the institutions, power politics and natural local conditions. There is a complex relationship between these elements. For success of any programme, proper configuration, manipulation and exploitation of these elements for advantage become necessary. Whoever, whether an individual or agency, is able to handle these judiciously will be a successful player. To some extent in this case the NGO has played more successfully than the government: an economic focus while ensuring support of cultural elements seems to yield better results.

Poverty in the area is closely associated with land and rainfall, but as agriculture is only a part of livelihood, the dynamics of poverty consists of a complex mix of processes, including migration. In order to understand the impact of the developmental interventions of the government and the NGO in ameliorating poverty, this study has taken an anthropological perspective of contextualizing development processes at the ground level. To conclude Kasi (2009b, 2011a) argued that poverty and vulnerability coexist and buttress each other and poverty can be understood by analyzing the real life situations and strategies adopted by the people to manage their lives.

\section{REFERENCES}

Bankoff, G., Geprge F., \& Dorothea, H. (2004). Mapping vulnerability, Sterling: Earthscan.

Baulch, B., \& Hoddinott, J. (2000). Economic mobility and poverty dynamics in developing countries. Journal of Development Studies, 36, 1-24. doi:10.1080/00220380008422652

Bird, K., Hulme, D., Moore, K., \& Shepherd, A. (2002). “Chronic Poverty and Remote Rural Areas” Institute for development policy and management. CPRC Working Paper No 13, Manchester: University of Manchester.

Broch-Due, V. (1995). Poverty and prosperity: Local and global perspectives. Uppsala: Nordiska Afrikainstitutet, Occasional Paper No. 1.

Booth, D., Melissa, L., \& Alison, T. (1999). Experiencing poverty in Africa: Perspectives from anthropology. World Bank Poverty Status Report Background Paper 1(b).

Banerjee, S., Angana, P. C., Lubna, N. C., Manali, D., Saadia, T., \& Kamala, V. (2004). Engendering violence: Boundaries, histories, and the everyday. In A. P. Chatterji, \& L. N. Chaudhry (Eds.), Gendered violence in South Asia: Nation and community in the postcolonial present, cultural dynamics: Theory cross-cultures, 16, 125-139.

Bhukya, B. (2010). Subjugated nomads: The Lambadas under the rule of the Nizams. Hyderabad: Orient BlackSwan.

Chatterji, A. P. (1998). Toward an ecology of hope. Community and joint forest management in Orissa. Sweden: Scandisconsult Natura AB; Berkeley: Asia Forest Network.

Chatterji, A. P. (2001). Postcolonial research as relevant practice (Postmodern research methods forum). TAMARA: Journal of Critical Postmodern Organization Science, 1, 1-13.

Devereux, S. (2001). Livelihood insecurity and social protection: A re-emerging issue in rural development. Development Policy Review, 19, 507-519. doi:10.1111/1467-7679.00148

Escobar, A. (1995). Encountering development: The making and unmaking of the Third World. Princeton: Princeton University Press.

Goody, J. (1971). The developmental cycle in domestic groups. Cambridge: Cambridge University Press.

Guru, G., \& Geetha, V. (2000). New phase of dalit-bahujan intellectual activity. Economic and Political Weekly, 35, 130-134.

Henninger, N. (1998). Mapping and geographic analysis of human welfare and poverty review and assessment. Washington DC: World Resources Institute.

http://www.grida.no/prog/global/poverty/pub/pov_fin.pdf 
Hulme, D., Moore, K., \& Shepherd, A. (2001). Chronic poverty: Meanings and analytical framework. CPRC Working Paper 2, Manchester: Institute for Development Policy and Management, University of Manchester.

Human Development Report (2000). Human Development Report 2000. New Delhi: Oxford University Press.

Ilaiah, K. (2009). Post-Hindu India: A discourse on Dalit-Bahujan, socio-spiritual and scientific revolution. New Delhi: Sage Publications.

Indian Social Institute (1988). The five year plan system. New Delhi: Indian Social Institute.

Kasi, E. (2011a). Poverty and development in a marginal community: Case study of a settlement of the Sugali Tribe in Andhra Pradesh, India. Journal of Asian and African Studies, 46, 5-18. doi:10.1177/0021909610388480

Kasi, E. (2009b). Poverty and vulnerability among tribal people: A case of Sugalis. In: Kasi, E., \& Malik, R. C. (Eds.), Theory and practice of ethnography: Readings from the periphery (pp. 337-354). Jaipur and New Delhi: Rawat Publications.

Kasi, E. (2009). Role of NGO in the development of Sugalis: Case study of a settlement in Andhra Pradesh. Human Ecology, 27, 115122.

Kasi, E. (2008). Poverty and development in a marginal community: Case study of a settlement of the Sugali tribe in Andhra Pradesh, India. South Asian Anthropologist, 8, 83-93.

Kasi, E. (2010). Fighting drought in the era of globalization: Programmes and schemes in Anantapur District of Andhra Pradesh. In M. C. Behere, \& J. Basar (Eds.), Developing the marginalised: Emerging issues and concerns (pp. 189-208). New Delhi: Commonwealth.

Kasi, E. (2007). An anthropological study of Livelihoods: The case of two Sugali settlements from Anantapur District of Andhra Pradesh. Un-published PhD thesis, Hyderabad: University of Hyderabad.

Kothari, U. (2002). Migration and chronic poverty. CPRC Working Paper 16, Manchester: Institute for Development Policy and Management, University of Manchester.

Kozel, V., \& Parker, B. (2001). Poverty in rural India: The contribution of qualitative research in poverty. Washington: World Bank.

Lanjouw, P., \& Stern, N. (1991). Poverty in Palanpur. The World Bank Economic Review, 5, 23-55. doi:10.1093/wber/5.1.23

Mani, D. (2001). Vulnerability analysis and asset mnagement. United Nations Centre for Regional Development (UNCRD).

Mehta, A. K., \& Shah, A. (2001). Chronic poverty in India: Overview study. CPRC Working Paper 7. Manchester: Institute for Development Policy and Management, University of Manchester.

Mehta, A. K., \& Shah, A. (2003). Chronic poverty in India: Incidence, causes and policies. World Development, 31, 491-511. doi:10.1016/S0305-750X(02)00212-7

Moser, C. (1998). The asset vulnerability framework: Reassessing urban poverty reduction strategies. World Development, 26, 1-19.
doi:10.1016/S0305-750X(97)10015-8

Oliver-Smith, A. (1996). Anthropological research on hazards and disasters. Annual Review of Anthropology, 25, 303-328. doi:10.1146/annurev.anthro.25.1.303

Pritchett, L., Asep, S., \& Sudarno, S. (2000). Quantifying vulnerability to poverty: A proposed measure, applied to Indonesia. Policy Research Working Paper 2437, Washington: The World Bank.

Rao, V. P. (2004). Dimensions of transformations in tribal societies with reference to Andhra Pradesh. New Delhi: Sarup and Sons.

Reddy, B. K. (1991). Forests and the Sugalis in Andhra Pradesh: Historical and anthropological perspective. Man in India, 71, 611-619.

Sainath, P. (1996). Everybody loves a good drought. New Delhi: Penguin.

Sah, D. C., \& Sisodia, Y. S. (2004). Editors introduction. In D. C. Sah, \& Y. S. Sisodia (Eds.), Tribal issues in India (pp. 15-36), Ujjain: MPISSR; Jaipur: Rawat Publications.

Sankaran, S. R. (2000). Welfare of scheduled castes and scheduled tribes in independent India-An overview of state policies and programmes. Journal of Rural Development, 19, 507-537.

Saxena, N. C. (2000a). How have the poor done? Mid-term review of the Ninth Plan. Economic and Political Weekly, 35, 3627-3630.

Schwegler, T., \& Michael, G. P. (2008). Unruly experts: Methods and forms of collaboration in the anthropology of public policy. Anthropology in Action: Journal for Applied Anthropology in Policy and Practice, 15, 1-9. doi:10.3167/aia.2008.150201

Sinha, S., \& Lipton, M. (1999). Damaging fluctuations, risk and poverty: A review. Background Paper for the World Development Report 2000/2001, Sussex: Poverty Research Unit, University of Sussex.

Smith, K. (1996). Environmental hazards: Assessing risk and reducing disaster. London: Routledge.

Social Education and Development Society (2004). Annual report of Social Education and Development Society, 2002-2004. Donor Agencies.

Tudawe, I. (2002). Chronic poverty and development policy in Sri Lanka: Overview study. CPRC Working Paper No. 9, Manchester: Institute for Development Policy and Management, University of Manchester.

UNDP (1997). India: The road to human development. New Delhi: United Nations Development Programme.

Unnikrishnan, N. (2000). Press and people: A manual of human rights reporting in India, 2000-2001. URL (last checked 11 October 2012). www.britishcouncil.org

Wisner, B. (1993). Disaster vulnerability: Scale, power and daily life. Geo-Journal, 30, 127-140. doi:10.1007/BF00808129

World Bank (2000). World Development Report 2000/2001 attacking poverty. Washington DC: World Bank.

World Bank (2000). World Development Report 2000/2001, Preventing Famines: The local press matters. Washington DC: World Bank. 